\title{
Comments on the Chemotherapy of Leprosy as Influenced by Present Knowledge of Mycobacterium leprae*
}

\author{
S. R. PATTYN \\ Professor of Bacteriology. \\ Instituut voor Tropische Geneeskunde Prins Leopold. \\ Antwerp. Belgium
}

\begin{abstract}
The chemotherapy of leprosy can now be based on firm laboratory knowledge about the responsible agent, $M y c o$. leprae, and the general principles applied in the management of tuberculosis. First-line and second-line drugs may be distinguished. At present there is no need to change the existing dosage of $600 \mathrm{mg}$ of dapsone (DDS) per week for mass campaigns.

Efforts should be made to find new treatment schedules leading to increased supervision by the application of intermittent therapy. In lepromatous cases, this intermittent schedule will probably have to be preceded by a preliminary course of continued therapy. It is possible that the use of rifampicin will appreciably shorten the period of treatment.
\end{abstract}

\section{Introduction}

Although an increasing number of new drugs have been introduced in the therapy of leprosy during the last three decades, their choice has been largely empirical, due to lack of knowledge about the responsible organism, Mycobacterium leprae, and the pathogenesis of the disease.

In the last 10 years, however, as a result of laboratory investigations, our knowledge and understanding of leprosy have increased more than in the 87 years between 1873 (when $M y c($ ). leprae was discovered) and 1960. In the latter year Shepard (1960a, b, 1962) demonstrated, using precisely defined conditions, that Myco. leprae multiplied in the footpads of mice. The second important discovery - the cellular type of immunity involved in leprosy-was made by Rees (Rees, 1966; Rees et al., 1967) who showed that a generalized infection resulted when thymectomized and irradiated mice were inoculated with Myco. leprae. Several authors have since shown that a cell-mediated type of immunity is involved in the human disease (Dierks and Shepard, 1968; Shepard, 1968; Turk and Waters, 1969).

These discoveries revealed new features about $M y c($ ). leprae, such as its long generation time (Shepard and McRae, 1965), the interpretation of irregularly stained organisms (Rees et al., 1960; Rees and Valentine, 1962; Shepard and McRae, 1965) and their quantitative assessment, using the Morphological Index

* Accepted for publication, 19 July, 1972. 
(M.I.). Moreover, a more accurate histo-pathological classification of the various forms of human leprosy was evolved by Ridley and Jopling (1966) by including immunological features of the disease. Finally, for the first time a rational approach to the evaluation of antileprosy drugs in mice and man was developed by including all these new parameters.

In mice, antileprosy drugs can be assessed in three ways: (1) by the continuous method (Shepard and Chang, 1962; Pattyn and Rooyackers, 1965; Rees, 1967a; Gaugas, 1967); (2) by the kinetic method; and (3) by treatment of an established infection (Shepard and Chang, 1967). In man, the activity of antileprosy drugs can be monitored by the regular inoculation into mice of $M y c($ ). leprae obtained from human biopsies taken during treatment (Shepard et al., 1968, 1969; Levy et al., 1969; Rees et al., 1970). These methods have revealed: (a) the time necessary for drugs to kill Myco( leprae (Shepard et al., 1968; Rees et al., 1970); (b) the existence of drug-resistant strains of Myco. leprae (Pettit et al., 1964, 1966a, b; Rees, 1967b; Pearson et al., 1968; Shepard et al., 1969); (c) the correlation existing between irregularly-stained forms of the bacilli and their inability to multiply, proving that non-solid $M y c$ o. leprae are dead.

There has been some divergence of opinion, and even scepticism, about the significance of the percentage of non-solid forms of the bacilli (Convit et al., 1970). Indeed, all morphological assessment is subjective. Therefore standard techniques in fixation, staining, observation and scoring must be used for determining the M.I. Perhaps some future histochemical method will supersede the counting of solidly staining (living) bacilli. At present the morphological criterion can only be checked by mouse inoculation, a technique that is entirely reliable (Levy e t al., 1970).

This newly acquired knowledge about $M y c o$. leprae, together with advances made in the management of tuberculosis, another chronic infectious disease, now provide a rational basis for studying leprosy therapy. In the chemotherapy of tuberculosis, experience has shown that successful or unsuccessful therapy, relapse, or drug resistance, is determined by the biological behaviour of the causative organism and the pharmacokinetics and pharmacology of the drugs used. Studies of all these aspects, together with controlled clinical trials, have led step by step to the development of completely successful therapeutic regimens, of which the latest is based on intermittent therapy (after an initial continuous period) allowing complete supervision (Stradling and Poole, 1963, 1970). While the importance of maintaining the prescribed therapy throughout for the successful treatment of chronic infections has been particularly appreciated and employed in tuberculosis, similar considerations seem to have been less rigorously applied to the treatment of leprosy.

There are three factors to be taken into account in planning a rational approach to drug therapy of chronic infections in general, and leprosy in particular. These are discussed below under the headings: the bacillus, the host, and the drug.

\section{The Three Interacting Factors in Drug Therapy}

\section{THE BACILLUS}

For a correct interpretation of events during the therapy of leprosy, the notion that non-solidly staining bacilli are incapable of multiplication is of great importance. It is now certain that, while a population of $M y c($ ). leprae may be killed by treatment within a few weeks or months, it may take 5 years or more 
for the bacilli to disappear from the skin or nasal mucosa. Thus the M.I. (if necessary checked by inoculation of bacilli from treated patients into mice) is of primary importance for following the effect of treatment (Shepard et al., 1968, 1969; Levy et al., 1969; Rees et al., 1970).

Since multiplication of Myco. leprae in the mouse footpad is limited to inocula of $10^{4}$ to $5 \times 10^{4}$ bacilli and the minimal infectious dose is between 3 and 10 organisms (Shepard and McRae, 1965), the sensitivity of the technique is of the order of $1 / 1000$ living bacilli.

The total bacillary population of a patient at the start of treatment not only determines the severity of the disease but also the number of pre-treatment drug-resistant bacilli. Indeed, in every bacterial population there exist resistant mutants to any drug, but these spontaneous mutants ("pre-treatment resisters") have an advantage over the larger, sensitive part of the population only when exposed to the drug. For most pathogenic organisms, such as Myco. tuberculosis. the frequency and level of drug-resistant mutants can be measured in vitro by counting the number of colonies in media containing known concentrations of the drug and seeded with known numbers of organisms (Canetti et al., 1961). In general, the frequency of such pre-treatment resistant organisms is of the order of 1 in $10^{6}$ to $10^{8}$. However, although similar in vitro determinations are not possible for $M y c($ ). leprae, drug resistance can be expected to arise in multi-bacillary types of leprosy (LL-BB) with between $10^{10}$ and $10^{12}$ organisms; but this is unlikely in the paucibacillary types (BT-TT).

The level of drug resistance of the "pre-treatment resisters" is also unknown for Myco. leprae. However, the large population of bacilli obtained in the immunologically deficient mouse might be sufficient to determine the level of drug resistance of these mutants. From available clinical data it appears that the degree of drug resistance is variable (Rees, 1967a, b; Pearson et al. , 1968).

\section{THE IMMUNOLOGICAL COMPETENCE OF THE HOST}

In the chemotherapy of most infectious diseases, the drug used accounts for the killing of the majority of the bacteria, while the defence mechanisms of the host deal with the remainder. In tuberculosis (Canetti, 1965), these residual organisms (drug-sensitive or drug-resistant) may persist, sometimes apparently in a dormant state, for a long time. In this situation, these organisms may begin to multiply again at any moment after treatment has ceased, and the patient relapses with a drug-sensitive or a drug-resistant infection.

In the patient with the lepromatous type of leprosy, the host has little or no capacity to destroy bacilli, and therefore all persisting and viable organisms will multiply again when treatment is stopped. This accounts for the high relapse rates reported in lepromatous leprosy: 12\% in India (Vellut, 1968) and 25\% in Latin America (Bechelli et al., 1970), and Hemerijckx (personal communication) recommends that lepromatous patients should be treated for life.

\section{THE DRUG}

(a) Minimal Inhibitory Concentration (M.I.C.). The M.I.C. of many drugs against Myco. leprae can now be determined by the mouse footpad technique. The results (Table 1 ) show that there is no correlation between the antibacterial activity of drugs against $M y c o$. tuberculosis or $M y c($. lepraemurium and $M y c o$. leprae.

(b) Serum concentration and half-life of the drug. This may show considerable individual variation, and therefore the lowest figures known are given (Table 1). 
TABLE 1

M.I.C. for several antileprosy drugs compared with serum concentrations obtained after current dosage

\begin{tabular}{|c|c|c|c|c|c|}
\hline Drug & $\begin{array}{l}\text { M.I.C. } \\
(\mu \mathrm{g} / \mathrm{ml})\end{array}$ & Dosage & Frequency & $\begin{array}{l}\text { Serum } \\
\text { concentration } \\
(\mu \mathrm{g} / \mathrm{ml})\end{array}$ & $\mathrm{x}$ \\
\hline DDS & $0.02-0.002$ & 100 & Daily & 2 & 100 \\
\hline DADDS & id. & $225 \mathrm{mg}$ & 1/77 days & 0.06 & 3 \\
\hline Sulfadime thoxine & 20 & $1.5 \mathrm{~g}$ & Daily & $150-300$ & $4-15$ \\
\hline Sulfadoxine & 20 & $1.5 \mathrm{~g}$ & 1/week & $150-300$ & $4-15$ \\
\hline $\begin{array}{l}\text { Sulfamethoxy pyri- } \\
\text { dazine }\end{array}$ & $0-35$ ? & $750 \mathrm{mg}$ & 1/2 days & $30-40$ & $4-15$ \\
\hline Clofazimine & \multicolumn{5}{|c|}{$\begin{array}{l}\text { Current dosage is } 100-200 \mathrm{mg} \text { per day } \\
\text { Minimal effective dosage in man calculated to correspond } \\
\text { to } 7 \mathrm{mg} \text { per day }\end{array}$} \\
\hline Thiambutosine & ? & $\begin{array}{l}3 \mathrm{~g} \\
\text { repository } \\
2 \mathrm{~g}\end{array}$ & $\begin{array}{l}\text { Daily } \\
\text { I/week }\end{array}$ & $?$ & \\
\hline Ethionamide & 25 & $250 \mathrm{mg}$ & Daily & $20-30$ & 1 \\
\hline
\end{tabular}

Genetic polymorphism in man has recently been described for the acetylation of dapsone (=inactivation) comparable to that shown for isoniazid (INH) (Gelber et al., 1969) and may be of practical importance when intermittent or low dosage DDS is administered, as was the case in intermittent treatment of tuberculosis with INH (Tuberculosis Chemotherapy Centre, Madras, 1970).

Another important point is the rate at which drugs kill Myco. leprae, for which the following results are available:

DDS: 90 days (Shepard et al., 1967, 1968)

Clofazimine (including DDS-resistant strains): more than 105 days (Levy et al., 1969)

Rifampicin: 3 to 24 days (Rees et al., 1970).

Thus, if a patient is treated with a drug having a high therapeutic activity, and he does not improve, or after some period of improvement there is clinical and bacteriological deterioration, there are only two explanations: either the infecting organism was or has become drug-resistant, or the patient failed to take or absorb the prescribed treatment (Poole and Stradling, 1960). This leads to the rather astonishing conclusion that in many cases the only advantage to be gained from determining the drug sensitivity of bacilli during treatment may be to demonstrate that the patient is taking the drug (McDermott, cited in Canetti, 1965). The persistent failure of leprosy patients to take their drugs regularly has been particularly well investigated by Pettit et al., (1966); some patients with lepromatous leprosy still active after more than 10 years' residence and treatment in a leprosarium, improved when the treatment was adequately supervised.

\section{The Possible Application of Principles Used in the Chemotherapy of Tuberculosis}

In the chemotherapy of tuberculosis a distinction is made between first-line drugs (low M.I.C., sustained serum levels many times higher than the M.I.C., minimum toxicity, and low incidence of pre-treatment resistant organisms) and 
second-line drugs (high M.I.C. and relatively low serum levels of shorter duration, resulting in more frequent resistance and/or higher toxicity). Treatment of multibacillary cases of tuberculosis with cavitation should always be initiated with 2 (preferably 3 ) major drugs in order to diminish the risk of the emergence of drug resistance, the frequency of double or triple drug resistance being of the order of $10^{-12}$ to $10^{-18}$. After a preliminary period of continuous double or triple treatment, reducing bacterial numbers drastically and thus the possibility of drug resistance, long-term monotherapy can safely be given (Canetti, 1968). To ensure that the drugs are being taken treatment should be supervised, and for practical purposes this is easier to achieve by an intermittent, rather than a daily, regimen (Poole et al., 1960; Stradling et al., 1963, 1970). Moreover, intermittent therapy has a theoretical advantage, because contact between the micro-organism and the drug is discontinuous. Thus the surviving organisms do not multiply again immediately, but only after a lag phase. This phenomenon has been demonstrated experimentally both in vitro and in vivo (Dickinson, 1968; Canetti, 1968). Experimental studies with $M y c o$. leprae on intermittent therapy in mice (Rees, 1965, 1967), using Shepard's kinetic methods (Levy, 1970), suggest that this phenomenon applies equally to leprosy.

\section{Treatment of Leprosy}

\section{DAPSONE}

The activity of substituted sulphones is entirely due to dapsone (4,4-diaminodiphenylsulphone, DDS), either liberated after administration or occurring as an impurity in some preparations (Shepard, 1969a; Shepard et al., 1969). The M.I.C. of dapsone for $M y c($. leprae is of the order of $0.02 \mu \mathrm{g}$ per $\mathrm{ml}$ serum, as determined by means of the mouse footpad model (Shepard et al., 1966; Shepard, 1967b; Rees, 1967). Because the metabolism of dapsone is similar in mouse and in man, the results obtained in the mouse are directly applicable to man. Experiments in man have shown this to be the case. Thus, the administration of $1 \mathrm{mg}$ of dapsone daily, or the intramuscular injection of $225 \mathrm{mg}$ of acedapsone (acetyl-diaminodiphenylsulphone, DADDS) every 77 days, produced respectively serum levels of 0.02 and $0.06 \mu \mathrm{g}$ per $\mathrm{ml}$ of dapsone and proved effective in the treatment of leprosy in man (Shepard et al., 1968; Waters et al., 1968).

When dapsone was introduced for the treatment of leprosy 30 years ago the dose chosen was based on the maximum amount tolerable (100 mg daily), because then the mouse model was not available (Lowe, 1954a, b). It is now proven that this dose produces serum levels of dapsone 100- to 300-fold the M.I.C. for $M y c o$. leprae. Present results in mouse and man suggest that therapeutically the dose of dapsone could be reduced, but lower doses might increase the incidence of drug resistance.

The observations of Pettit et al. (1966), Shepard et al. (1969), and Browne (1969) have shown that DDS resistance can occur in some lepromatous patients on standard, irregular, or smaller (50 mg twice weekly) doses of dapsone. Resistance may well arise if acedapsone, $225 \mathrm{mg}$ every 77 days, is used on a large scale. However, because of the long generation time of Myco. leprae, it may take 3 or more years before dapsone-resistant mutants give rise to clinical evidence of relapse. The rarity of dapsone resistance noted during the 30 years of standard dapsone monotherapy is probably because there are very few high-resistant mutants capable of growing at the high concentrations of dapsone obtained. 
For the treatment of tuberculoid leprosy, in which there is a small bacterial population and therefore fewer resistant mutants than in patients with lepromatous leprosy, lower doses of dapsone (1/10th of the standard dose) could be adequate. However, because of the low cost and low toxicity of dapsone in the standard dosage, smaller doses would have no practical advantages, whereas one standard dose for all types of leprosy would be advantageous.

For the treatment of lepromatous leprosy, lower doses of dapsone are much more likely to give rise to resistance, particularly if taken irregularly. Therefore lower doses of dapsone in lepromatous leprosy could be justified only when preceded by an initial period of standard doses (100 mg) intended to diminish the bacterial load considerably without danger of selection of resistant organisms. Lower doses are also justified when they are attained by intermittent therapy and therefore increase the possibility of supervised treatment. It is possible that, in the past, standard doses of dapsone (100 mg daily) were curative even in those patients who, after an initial period of regular treatment, became irregular, but took sufficient dapsone to produce active drug levels in the serum. This possibility is based on the fact that serum levels of dapsone obtained from standard treatment are 100- to 300-fold greater than the M.I.C. of dapsone for Myco. leprae.

Thus it would seem important to initiate controlled clinical trials in patients with lepromatous leprosy, with 4 to 6 months high dose $(100 \mathrm{mg})$ continuous dapsone therapy, followed by supervised intermittent therapy, for example, $25 \mathrm{mg}$ dapsone twice weekly per os, or once weekly long-acting sulphonamides, or injections of acedapsone (DADDS) every 77 days (Shepard et al., 1968).

As has already been mentioned, relapses can be due either to drug-sensitive persisters multiplying after therapy has been stopped, or to the emergence of drug-resistant mutants. To determine the cause of such relapses, the sensitivity of the organisms can be tested in the mouse. However, the patient who has relapsed should also be put on a supervised test-period for 3 months on full-dose dapsone and any change in the morphological index used as an indirect method to detect a dapsone-sensitive or dapsone-resistant infection. This clinical method is more rapid than the mouse test. If it is confirmed that the histoid type of leprosy is always associated with dapsone-resistant organisms (Rodriguez, 1969), histopathological examination would rapidly resolve the question.

\section{LONG-ACTING SULPHONAMIDES}

Sulphones and sulphonamides both interfere with folate metabolism (Shepard, 1967) and cross-resistance between the two types of drug exists (Adams and Waters, 1966). Some sulphonamides were tried in the treatment of leprosy before the sulphone era (Schneider et al., 1959); they were reintroduced as a result of a chance observation (Schneider et al., 1959). The dose of sulphonamides for leprosy was chosen empirically and resulted in serum levels of 30 to $40 \mu \mathrm{g}$ per ml (Schneider et al., 1959; Languillon, 1964; Languillon and Carayon, 1969). Ellard et al. (1970) found the M.I.C. against Myco. leprae in the mouse for sulphadimethoxine and sulphadoxine to be 20 and $35 \mu \mathrm{g}$ per $\mathrm{ml}$ respectively, and the calculated serum levels attained in man with these two drugs to be 150 and $300 \mu \mathrm{g}$ per $\mathrm{ml}$ respectively. Since these serum levels are only 4 to 15 times higher than the M.I.C., Ellard et al. (1970) warned that sulphonamide resistance and, because of cross-resistance, sulphone resistance might result from treating patients with lepromatous leprosy with these drugs. Sulphonamide resistance has been 
observed in man (Merklen et al., 1968) and most authors (Schneider et al., 1959; Litalien et al., 1961; Languillon, 1964) consider sulphonamide treatment to give better results in tuberculoid than in lepromatous leprosy. The laboratory findings indicate that the use of long-acting sulphonamides should be limited to the treatment of tuberculoid leprosy, and, in lepromatous leprosy, as intermittent therapy following initial treatment with a bactericidal drug.

\section{CLOFAZIMINE (B663)}

Current dosage, again empirically determined, has been between 100 and $200 \mathrm{mg}$ per day. Since this drug has different affinities for different tissues, dosage cannot be based on the M.I.C. and serum levels. However, Shepard (1969b) calculated the minimal effective dosage in man to be $7 \mathrm{mg}$ per day. Studies by Levy et al. (1969) on the killing rate of Myco. leprae by clofazimine showed it to be somewhat slower than that of dapsone. Clofazimine is an important drug because of its low toxicity, high activity, and absence of cross-resistance with the sulphones or sulphonamides. Its great disadvantage is the skin pigmentation it induces, which is unacceptable to many patients. Some patients, however, appreciate this discoloration (Renders, 1968), and on the other hand it confirms that the patient is taking the drug.

Where skin pigmentation is a major obstacle, a dose of $200 \mathrm{mg}$ per week (Waters et al., 1968) would probably be adequate for patients with tuberculoid leprosy or as a secondary drug for patients with lepromatous leprosy following initial therapy with a bactericidal drug. Controlled trials along these lines seem indicated.

\section{RIFAMPICIN}

The M.I.C. of rifampicin for Myco. leprae has not yet been determined. However, its extraordinarily rapid killing effect on $M y c 0$. leprae is well known. Thus, it has been observed both in man (Rees et al., 1970; Leiker et al.. 1970, and our own unpublished observations) and in the mouse (Shepard, 1971) that 2 days' treatment with rifampicin is as effective as 2 to 3 months of dapsone. Grumbach et al. (1969) considered that, for tuberculosis, rifampicin, in spite of its price, would be advantageous by shortening the duration of therapy. Future studies will determine whether a relatively short course of rifampicin will cure tuberculoid leprosy. In lepromatous leprosy, rifampicin might with advantage be given initially and continuously for a relatively short period, say 3 months, followed by intermittent treatment with either acedapsone, a sulphonamide, or clofazimine. Laboratory controlled treatment schemes along these lines are recommended.

\section{THIAMBUTOSINE (DPT)-THIACETAZONE (TB1)-ETHIONAMIDE}

The appearance of resistance to these drugs after 1 to 2 years of treatment is a regular phenomenon (Lowe, 1954b; Davey, 1955, 1960) and many resistant strains have been isolated in mice (Shepard, 1969; Rees, 1967b; Pattyn et al., 1965). This must be due to the low serum levels attained with the current dosages and these cannot be increased because of the high risk of toxic side-effects (Cochrane and Davey, 1964). Thus thiambutosine is only a "second line drug" for leprosy; it took many years to reach this conclusion, despite the fact that thiambutosine was the second antileprosy drug discovered. The delay was due to the lack of suitable laboratory techniques which are now available. Ethionamide is also a "second line drug" that develops cross-resistance with related drugs (Floch 
et al., 1966). The M.I.C. of ethionamide for Myco. leprae in the mouse is $25 \mu \mathrm{g}$ per $\mathrm{ml}$ (Shepard, 1969b). This value is.very close to the serum levels calculated to attain 20 to $30 \mu \mathrm{g}$ per $\mathrm{ml}$ when given at a dosage of $250 \mathrm{mg}$ daily, as was done by Floch et al. (1966). These authors found ethionamide to be active, but the duration of the trial was manifestly too short ( 4 to 18 months). Moreover, with the additional knowledge that ethionamide is rapidly excreted, that inhibition of the growth of Myco. leprae is of short duration (Shepard, 1969), and that the dosage cannot be increased for long-term treatment (because of toxicity), it is clear that ethionamide will remain at best a second-line drug.

\section{Treatment of Patients with Drug-resistant Organisms}

The occurrence of drug resistance to thiambutosine and dapsone is wellestablished. Because thiambutosine is a second-line drug in leprosy, it should not be administered alone at the start of treatment of patients with multibacillary disease. Cases resistant only to thiambutosine are not a therapeutic problem, since first-line drugs will still be effective. However, patients who are resistant to dapsone need special attention for two reasons. The first is the potential danger of spread of dapsone-resistant strains of $M y c o$. leprae in the community, although nothing is yet known about their infectiousness for man. For the present, dapsone-resistant strains should be considered infectious for $\mathrm{m}$ an; for the mouse, they are as infectious as dapsone-sensitive strains. The second reason is psychological. If dapsone resistance appears in a patient for whom high dosage dapsone (500 to $600 \mathrm{mg}$ per week) has been prescribed, then he has probably taken the drug irregularly and not in the way prescribed. He may well be irregular with any new therapy and therefore will relapse again. Such patients present individual and community problems. Moreover, their apparently "uncured leprosy" may be quoted or used by others to prove, wrongly, that "leprosy is incurable".

Rifampicin and clofazimine are fully effective against dapsone-resistant strains of Myco. leprae in the mouse, and therefore are the drugs of choice for the treatment of patients with dapsone-resistant bacilli. Determination of the level of dapsone-resistance is only useful for identifying patients with intermediate levels of resistance, still capable of responding to full doses of dapsone $(100 \mathrm{mg}$ per day). However, for such patients dapsone should be given only in combination with one or two other antileprosy drugs.

\section{References}

Adams, A. R. D. and Waters, M. F. R. (1966). Dapsone resistant lepromatous leprosy in England. Br. med.J. ii, 872 .

Bechelli, L. M. and Guinto, R. S. (1970). Some recent laboratory findings on Mycobacterium leprae. Bull. Wld Hlth Org. 43, 559.

Browne, S. G. (1969). Dapsone resistant Mycobacterium leprae in a patient receiving dapsone in low dose. Int. J. Lepr. 37, 296.

Canetti, G. (1965). Present aspects of bacterial resistance in tuberculosis. Am. Rev. resp. Dis. 92,687 .

Canetti, G. (1968). Experiments with long-term intermittent chemotherapy in advanced tuberculosis in mice. Tubercle (Lond.) 49 (Suppl.) 70. 
Canetti, G. and Grosset, J. (1961). Teneur des souches sauvages de Mycohacterium tuherculosis en variants résistants à l'isoniazide et en variants résistants à la streptomycine sur milieu de Loewenstein-Jensen. Ann. Inst. Pasteur 101, 28.

Cochrane, R. G. and Davey, F. T. (1964). Leprosy in Theory and Practice, 2nd ed. Bristol: J. Wright \& Sons Ltd.

Convit, J., Browne, S. G., Languillon, J., Pettit, J. H. S., Ramanujam, K., Sagher, F., Sheskin, J., De Souza-Lima, L., Tarabini, G., Tolentino, J. G., Waters, M. F. R., Bechelli, L. M. and Martinez Dominguez, V. (1970). Therapy of leprosy. Bull. Wld Hlth Org. 42, 667.

Davey, T. F. (1955). Editorial. Leprosy treatment in East Nigeria. Lepr. Rev. 26, 8.

Davey, T. F. (1960). Some recent chemotherapeutic work in leprosy. Trans. R. Soc. Trop. Med. Hyg. 54, 199.

Dickinson, J. M. (1968). In vitro and in vivo studies to assess the suitability of antituberculous drugs for use in intermittent chemotherapy regimens. Tubercle (Lond.) 49 (Suppl.) 66.

Dierks, R. E. and Shepard, C. C. (1968). Effects of phytohemagglutinin and various mycobacterial antigens on lymphocyte cultures from leprosy patients. Proc. Soc. exp. Biol. Med. 127, 391 .

Ellard, G. A.. Gammon. P. T. and Rees. R. J. W. (1970). The minimal inhibitory concentrations of sulphadimethoxine and sulphadoxine against Mycohacterium leprae. Lepr. Rev. 41, 223.

Floch, H., Rist, N. and Jacobi, J. C. (1966). Intérêt de l'éthionamide en thérapeutique antilépreuse. Bull. Soc. Path. Exot. 59, 715.

Gaugas, J. M. (1967). Antimicrobial therapy of experimental human leprosy (Mycohacterium leprae) infection in the mouse footpad. Lepr. Rev. 38, 225.

Gelber, R., Glazka, A. J., Peters, J. H. and Levy, L. (1969). A comparison of dapsone and isoniazid acetylation in humans. Int. J. I.epr. 37, 463.

Grumbach, F., Canetti, G. and Le Lirzin, M. (1969). Rifampicin in daily and intermittent treatment of experimental murine tuberculosis, with emphasis on late results. Tubercle (Lond.) 50, 280.

Languillon, J. (1964). La sulfamidothérapie dans la lèpre. Méd. Trop. 24, 520.

Languillon, J. and Carayon, A. (1969). Précis de Léprologie. Paris: Masson et Cie.

Leiker, D. L. and Kamp, H. (1970). First results of treatment of leprosy with Rifadin. Lepr. Rev. $41,25$.

Levy, L. (1970). Death of Mycohacterium leprae in mice and the additional effect of dapsone administration. Proc. Soc. exp. Biol. Med. 135, 745.

Levy, L., Murray, L. P. and Shepard, C. C. (1970). A comparative study of mouse footpad inoculation of skin biopsy specimens from patients with lepromatous leprosy in San Francisco and Atlanta. Int. J. Lepr. 38, 54.

Levy, L., Shepard, C. C. and Fasal, P. (1969). Killing of dapsone-resistant Mycohacterium leprae during treatment with B663. Int. J. Lepr. 37, 466.

Litalien, F., Harter, P., Trinkhthikim-Mong-Don and Nguyen-Thi-Lau (1961). Essai de traitement de la lèpre lépromateuse par la sulfaméthopyrazine. Bull. Soc. Path. Exot. 54, 219

Lowe, J. (1954a). The chemotherapy of leprosy. Late results of treatment with sulphone and with thiosemicarbazone. Lancet ii, 1065.

Lowe, J. (1954b). The late results of sulphone treatment of leprosy in East Nigeria. Lepr. Rev. $25,113$.

Merklen, F. P., Cottenot, F. and Egger, L. (1968). Reprises et aggravation d'une lèpre tuberculoide à la suite d'arrêts thérapeutiques répétés. Bull Soc. Franc. Derm. Syph. 75, 188

Pattyn, S. R. and Rooyackers, J. (1965). Traitement de l'infection expérimentale à Mycobacterium leprae chez la souris. Ann. Soc. Belge. Méd. Trop. 45, 27.

Pearson, J. M. H., Pettit, J. H. S. and Rees, R. J. W. (1968). Studies on sulf one resistance in leprosy. 3. A case of partial resistance. Int. J. Lepr. 36, 71.

Pearson, J. M. H. and Pettit, J. H. S. (1969). Chemotherapeutic trials in leprosy. 7. Trial of $50 \mathrm{mg}$ DDS twice weekly in the treatment of lepromatous leprosy. Int. J. Lepr. 37, 40.

Pearson, J. M. H., Rees, R. J. W. and Weddell, A. G. M. (1970). Mycobacterium leprae in the striated muscle of patients with leprosy. Lepr. Rev. 41, 155.

Pettit, J. H. S. and Rees, R. J. W. (1964). Sulphone resistance in leprosy. An experimental and clinical study. Lancet ii, 673.

Pettit, J. H. S., Rees, R. J. W. and Ridley, D. S. (1966). Studies on sulfone resistance in leprosy. 1. Detection of cases. 2. Treatment with a riminophenazine derivative (B663). Int. J. Lepr. 34, 375, 391 . 
Poole, (B. and Stradling, P. (1960). Chemotherapeutic pitfalls in the treatment of tuberculosis. Brit. med. I. i, 160.

Rees, R. J. W. (1965). Recent hacteriologic and pathologic studies on experimental human leprosy in the mouse footpad. Int. I. lepr. 33, 646.

Rees, R. J. W. (1966). Enhanced susceptibility of thymectomized and irradiated mice to infection with Mycohacterium leprae. Nature (L.ond.) 211,657.

Rees, R. J. W. (1967a). A preliminary review of the experimental evaluation of drugs for the treatment of leprosy. Trans. R. Soc. Trop. Med. Hyg. 61, 581.

Rees, R. J. W. (1967b). Drug resistance of Mycobacterium leprae, particularly to DDS. Int. J. l.epr. 35,625 .

Rees, R. J. W. (1969). New prospects for the study of leprosy in the laboratory. Bull. Wld Hlth Org. 40, 785 .

Rees, R. J. W., Valentine, R. C. and Wong, P. C. (1960). Application of quantitative electron microscopy to the study of M»cohacterium lepraemurium and Mycohacterium leprae. I. gen. Microbiol. 22, 443.

Rees, R. J. W. and Valentine, R. C. (1962). The appearance of dead leprosy bacilli by light and electron microscopy. Int. .I. L.epr. 30, 1 .

Rees, R. J. W., Waters, M. F. R., Weddell, A. (;. M. and Palmer, E. (1967). Experimental lepromatous leprosy. Nature (I.ond.) 215,599 .

Rees, R. J. W., Pearson, J. M. H. and Waters, M. F. R. (1970). Experimental and clinical studies on rifampicin in treatment of leprosy. Brit. med. J. $i, 89$.

Renders, A. (1968). Essai d'un lèprostatique récent (B663) dans le traitement de la lèpre léprostatique. Ann. Soc. Belge Méd. Trop. 48, 625.

Ridley, I. S. and Jopling, W. H. (1966). Classification of leprosy according to immunity. A five-group system. Int. J. L.epr. 34, 255.

Rodriguez, J. N. (1969). The histoid leproma. Its characteristics and significance. Int. J. Lepr. 37,1 .

Schneider, J., Languillon, J. and Clary, J. (1959). Traitement de la lèpre par un nouveau sulf amide: la sulfaméthopyrazine. Premiers résultats. Bull. Soc. Path. Exot. 52, 47.

Shepard, C. C. (1960a). The experimental disease that follows the injection of human leprosy bacilli into footpads of mice. J. exp. Med. 112, 445

Shepard, C. C. (1960)b). Acid-fast bacilli in nasal excretions in leprosy and results of inoculation of mice. Am. J. Hyg. $71,147$.

Shepard, C. C. (1962). Multiplication of Mycohacterium leprae in the footpad of the mouse. Int. J. Lepr. 30, 291.

Shepard, C. C. (1967a). A kinetic method for the study of activity of drugs against Mycohacterium leprae. Int. J. Lepr. 35, 52.

Shepard, C. C. (1967b). Activity of repository sulfones against Mycobacterium leprae in mice. Proc. Soc. exp. Biol. Med. 124, 430.

Shepard, C. C. (1968). Immunologic suppression in leprosy and its relation to lepromatous disease. Int. J. L.epr. 36, 87.

Shepard, C. C. (1969a). Chemotherapy of leprosy. A m. rev. Pharmacol. 9, 37.

Shepard, C. C. (1969b). Minimal effective dosages in mice of clofazimine (B663) and of ethionamide against Mycobacterium leprae. Proc. Soc. exp. Biol. Med. 132, 120.

Shepard, C. C. (1971). Rifampicin vs Mycobacterium leprae. Proc. VIth Annual Leprosy Research Conference, Atlanta, Ga. 10-12, 3.

Shepard, C. C. and Chang, Y. T. (1962). Effect of several anti-leprosy drugs on multiplication of human leprosy bacilli in footpads of mice. Proc. Soc. exp. Biol. Med. 109, 636.

Shepard, C. C. and Chang, Y. T. (1967). Effect of DDS on established infections with Mycobacterium leprae in mice. Int. J. Lepr. 35, 52.

Shepard, C. C., Levy, L. and Fasal, P. (1968). The death of Mycobacterium leprae during treatment with 4-4'-diaminodiphenylsulf one (DDS). A m. J. Trop. Med. Hyg. 17, 769.

Shepard, C. C., Levy, L. and Fasal, P. (1969). The sensitivity to dapsone (DDS) of Mycobacterium leprae from patients with and without previous treatment. Am. J. Trop. Med. Hyg. 18, 258.

Shepard, C. C. and McRae, D. H. (1965). Mycobacterium leprae in mice: Minimal infectious dose, relationship between staining quality and infectivity, and effect of cortisone. $J$. Bact. 89, 365 .

Shepard, C. C., McRae, D. H. and Habas, J. A. (1966). Sensitivity of Mycobacterium leprae to low levels of 4-4'-diaminodiphenylsulfone. Proc. Soc. exp. Biol. Med. 122, 893. 
Shepard, C. C., Tolentino, J. G. and McRae, D. H. (1968). The therapeutic effect of 4-4'-diacetyldiaminodiphenylsulfone. Am. J. Trop. Med. Hyg. 17, 192.

Stradling, P. and Poole, G. (1963). Towards foolproof chemotherapy for tuberculosis. Tuhercle (Lond.) 44, 71 .

Stradling, P. and Poole, G. (1970). Twice weekly streptomycin plus isoniazid for tuberculosis. Tubercle (Lond.) $51,44$.

Tuberculosis Chemotherapy Centre, Madras (1970). A controlled comparison of a twice-weekly and three once-weekly regimens in the initial treatment of pulmonary tuberculosis. Bull. Wld Hlth Org. 43, 143.

Turk, J. L. and Waters, M. F. R. (1969). Cell-mediated immunity in patients with leprosy. Lancet ii, 243.

Vellut, C. (1968). Ten years follow-up of lepromatous leprosy patients and DDS treatment. Leprosy in India 40, 111 .

Note added in proof. Since the submission of this manuscript, Holmes and Hilson (J. med. Microbiol., $1972,5,251)$ have published the results of rifampicin treatment of the experimental infection of mice by Myco. leprae. The results indicate that rifampicin is very rapidly bactericidal and that the MIC is around $0.3 \mathrm{\mu g} / \mathrm{ml}$ whereas the serum concentration attained in man during rifampicin treatment with $600 \mathrm{mg} / \mathrm{day}$ "fluctuates through the day from about $15 \mu \mathrm{g} / \mathrm{ml}$ to $0.5 \mu \mathrm{g} / \mathrm{ml}$ ". The bactericidal effect of rifampicin on Myco. leprae was confirmed in the mouse model. 